Original Research Article

\title{
Identification of issues and priority actions for Restoration of freshwater ecosystem: River Ganga (Kanpur to Bihar)
}

Barik, Disha Ashok and Kimmatkar, Ketan

Institute of Design Education and Architectural Studies, Nagpur.

Corresponding Author: disha.sonkusare@gmail.com

\section{A R T I C L E I N F O}

Received: 19 July 2018 | Accepted: 22 October 2018 | Published Online: 31 December 2018

DOI: $10.31786 / 09756272.18 .9 .2 .215$

EOI: 10.11208/essence.18.9.2.215

Article is an Open Access Publication.

This work is licensed under Attribution-Non Commercial 4.0 International

(https://creativecommons.org/licenses/by/4.0/)

CThe Authors (2018). Publishing Rights @ MANU_ICMANU \& ESSENCE_IJERC.

\section{A B S T R A C T}

In order to reduce Pollution of river Ganga and its Ecosystem which has been disturbed by human interventions and anthropogenic activities, had led to the degradation of the water quality of freshwater ecosystem. GOI launched Ganga Action Plan in 1985 were at-tempts had been made to control, improve and maintain ecological integrity of the ecosystem by physical, chemical and biological methods. Rapid urbanization, industrialization besides agriculture using chemical fertilizers and pesticides, which is directly released in the basin, have degraded the water quality. The paper deals with the impact of technical interventions in the form of liquid and solid wastes, carried by the river are the issues and challenges for the ecosystem. Besides these, there are some suggestions and recommendations to minimize the ecological degradation of the river to restore its ecology. The measures include active as well as passive restoration techniques to bring back the sustainable ecosystem of River Ganga

\section{K E Y W O R D S}

Species-diversity | Various Pollutants | Threats | Disturbances in Ecology | Conservation tools

\section{I T A T I O N}

Barik, D. A. and Kimmatkar, K. (2018): Identification of issues and priority actions for Restoration of freshwater ecosystem-river Ganga- (Kanpur to Bihar) stretch. ESSENCE Int. J. Env. Rehab. Conserv. IX (1): $101-111$ 


\section{Introduction}

Ganga river basin-is the freshwater ecosystem and is the largest of these. It originates from the ice caves at Gaumukh $\left(\mathrm{N} 30^{\circ} 55^{\prime}\right.$, E $\left.79^{\circ} 7^{\prime}\right)$ and traverses a distance of $\approx 2510 \mathrm{~km}$ from its source to its mouth (Ganga Sagar), draining eleven states of India. The river Ganga is home to a vast variety theology but are different in terms of issues that need to be addressed:
A. Upper Ganga $\approx 294 \mathrm{~km}$ Gaumukh to Haridwar
B. Middle Ganga $\approx 1082 \mathrm{~km}$ Haridwar to Varanasi (Kanpur to Bihar) stretch

C. Lower Ganga $\approx 1134 \mathrm{~km}$ Varanasi to Ganga Sagar.

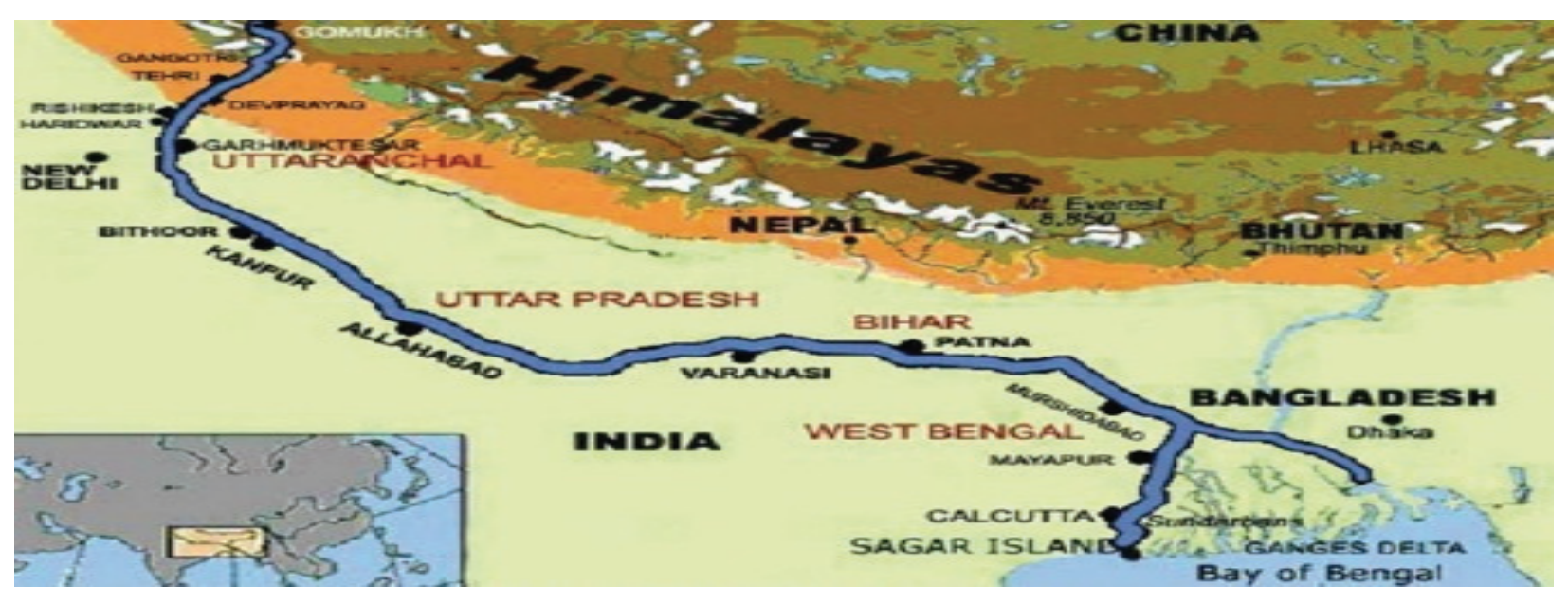

Fig-1: Represents critically polluted stretch, Source: Status paper on river Ganga

of living organisms from simple microscopic flora and fauna to a large assemblage of higher invertebrates and vertebrates .River quality is day by day deceased due to domestic and industrial effluents pollution threatens not only humans, but also more than 130 fish species, 83 amphibian species and the endangered Ganga river dolphin. Due to industrialization, the number of factories and population has increased rapidly. The riverine systems has be greatly infected with pollutants released from industrial, domestic, mining and agricultural effluents.

Common carp and Tilapia are are commercially exploited species in Ganga which are used to evaluate the health of aquatic ecosystems because pollutants are building up in the food chain and are responsible for adverse effects and death in the freshwater ecosystems. The entire stretch of river Ganga (main stream) can be viewed into three segments where each segment is further divided into 5 stretches. These three segments not only differ in their geomorphology, ecology and

\section{Originally the ecological setup of river Ganga}

Ganga is a prime example of lotic ecosystem. It is referred as running water ecosystem, which has current were in, water is in motion. Before 30 years, the values of dissolved oxygen (DO) exhibited a more or less stable pattern in Ganga. The average values ranged between 6.8-7.2 mg/l. The values were generally above $4.0 \mathrm{mg} / \mathrm{l}$. Higher values were recorded in winters at Haridwar, Allahabad, Varanasi and Patna. There were only minor fluctuations. Biochemical oxygen demand (BOD) - depicts the pollution status of a stream and is measured as oxygen equivalent of organic matter. The values exhibited higher pollution level higher which was recorded at Kanpur downstream $15.5 \mathrm{mg} / 1,14.15 \mathrm{mg} / \mathrm{l}, 16.39 \mathrm{mg} / \mathrm{l}$ and Coliformthe variation in total coliforms was 48333, 916667 and $835333 \mathrm{mpn} / 100 \mathrm{ml}$. The stretch from Kanpur - Varanasi- Bihar remains critical and needs focused attention.

Further, Ganga passes along 29 class-I cities and about 48 towns. Most of the cities had no Sewagd 
Treatment Plants or even if the plants existed, they were not functional or needed augmentation. There were several polluted stretches along its course where Ganga was critically polluted at Middle Ganga stretch \{Kanpur-Bihar\} as shown in (Fig-1)
Among the pollutants, toxic metals are of serious concern because they accumulate through the food chain and create environmental problems. Higher concentrations of heavy metals such as Mercury, Cadmium, Nickel, Lead, Arsenic, Zinc, Copper, Chromium. From industries forms

Water Quality Data of Ganga River During 1986-2008

\begin{tabular}{|c|c|c|c|c|c|c|c|c|c|c|c|c|c|c|}
\hline \multirow[t]{2}{*}{$\begin{array}{l}\text { SI } \\
\text { No }\end{array}$} & \multirow[t]{2}{*}{ Station/ Location } & \multirow[t]{2}{*}{$\begin{array}{l}\text { Distance } \\
\text { in km }\end{array}$} & \multicolumn{2}{|l|}{1986} & \multicolumn{2}{|l|}{1993} & \multicolumn{2}{|l|}{2002} & \multicolumn{2}{|l|}{2005} & \multicolumn{2}{|c|}{2008} & \multicolumn{2}{|c|}{$\begin{array}{l}\text { Standard } \\
\text { values }\end{array}$} \\
\hline & & & $\begin{array}{l}\text { DO } \\
\text { (mg/l) }\end{array}$ & $\begin{array}{l}B O D \\
(\mathrm{mgl})\end{array}$ & $\begin{array}{l}\text { DO } \\
(\mathrm{mg} / \mathrm{l})\end{array}$ & $\begin{array}{l}B O D \\
\text { (mgl) }\end{array}$ & $\begin{array}{l}\text { DO } \\
\text { (mgl) }\end{array}$ & $\begin{array}{l}\text { BOD } \\
(\mathrm{mg} / \mathrm{l})\end{array}$ & $\begin{array}{l}\text { DO } \\
\text { (mgl) }\end{array}$ & $\begin{array}{l}B O D \\
(\mathrm{mg} / \mathrm{l})\end{array}$ & $\begin{array}{l}\text { DO } \\
\text { (mgl) }\end{array}$ & $\begin{array}{l}\text { BOD } \\
(\mathrm{mg} / \mathrm{l})\end{array}$ & $\begin{array}{l}\text { DO } \\
\text { (mgn) }\end{array}$ & $\begin{array}{l}\text { BOD } \\
(\mathrm{mgl})\end{array}$ \\
\hline 1 & Rishikesh $(0 \mathrm{~km})$ & 0 & 8.1 & 1.7 & 9.0 & 1.3 & 8.2 & 12 & 8.5 & 1.0 & 81 & 12 & 5.0 & 3.0 \\
\hline 2 & Haridwar D/s $(30 \mathrm{~km})$ & 30 & 8.1 & 1.8 & 7.2 & 1.4 & 78 & 1.7 & 8.1 & 1.4 & 79 & 1.4 & 5.0 & 3.0 \\
\hline 3 & Gahmuktes hwar $(175 \mathrm{~km})$ & 175 & 7.8 & 22 & 8.5 & 1.6 & 7.5 & 2.1 & 7.8 & 20 & 7.8 & 1.9 & 5.0 & 3.0 \\
\hline 4 & Kannaú U/S (430 km) & 430 & 72 & 5.5 & 7.2 & 2.3 & 77 & 1.2 & 8.5 & 1.7 & 6.5 & 2.9 & 5.0 & 30 \\
\hline 5 & Kannaú DIS (433 km) & 433 & 6.5 & 5.1 & 84 & 25 & 6.5 & 42 & 7.6 & 4.5 & 62 & 3.1 & 5.0 & 3.0 \\
\hline 6 & Kanpur US $(530 \mathrm{~km})$ & 530 & 72 & 72 & 7.5 & 1.9 & 63 & 3.8 & 62 & 43 & 49 & 3.4 & 5.0 & 3.0 \\
\hline 7 & Kanpur DIS $(548 \mathrm{~km})$ & 548 & 6.7 & 8.6 & 5.2 & 24.5 & 6.7 & 4.9 & 4.7 & 5.4 & 6.0 & 4.1 & 5.0 & 3.0 \\
\hline 8 & Allahabad UIS (733 km) & 733 & 6.4 & 11.4 & 6.9 & 1.8 & 130 & 8.0 & 8.5 & 5.5 & 84 & 4.8 & 5.0 & 3.0 \\
\hline 9 & Alahabad DIS $(743 \mathrm{~km})$ & 743 & 6.6 & 15.5 & 7.2 & 1.9 & 8.2 & 3.8 & 8.4 & 3.1 & 7.7 & 3.2 & 5.0 & 3.0 \\
\hline 10 & Varanasi U/S (908 km)) & 908 & 5.6 & 10.1 & 8.2 & 0.8 & 10.8 & 3.0 & 8.6 & 20 & 7.5 & 2.2 & 5.0 & 3.0 \\
\hline 11 & Varanasi DIS (916 km) & 916 & 5.9 & 10.6 & 7.6 & 1.0 & 7.5 & 2.5 & 83 & 23 & 73 & 3.0 & 50 & 3.0 \\
\hline 12 & Patna UIS (1188 km) & 1188 & 8.4 & 20 & 8.2 & 1.2 & 7.1 & 1.9 & 7.4 & 20 & 6.0 & 1.7 & 5.0 & 3.0 \\
\hline 13 & Patna DIS (1198 km) & 1198 & 8.1 & 2.2 & 80 & 1.5 & 7.1 & 2.0 & 8.0 & 2.2 & 5.9 & 2.4 & 5.0 & 3.0 \\
\hline 14 & Rajmahal (1508 km) & 1508 & 7.8 & 1.8 & 8.5 & 0.7 & 7.9 & 1.5 & 7.4 & 1.8 & 62 & 2.0 & 5.0 & 30 \\
\hline 15 & Patna (2050 km) & 2050 & 7.3 & 1.0 & 7.1 & 0.9 & 7.3 & 2.7 & 7.0 & 3.0 & 6.9 & 2.2 & 5.0 & 30 \\
\hline 16 & Ulberia $(2500 \mathrm{~km})$ & 2500 & 5.8 & 1.1 & 6.1 & 0.9 & 5.4 & 1.9 & 5.4 & 26 & 5.3 & 3.6 & 5.0 & 3.0 \\
\hline
\end{tabular}

Table 1: Represents water quality data of Ganga River during 1986- 2008 Source: Status paper on river Ganga

\section{Present scenario}

According to the latest update received by $\mathrm{CPCB}$, the actual measured discharge of wastewater is $6087 \mathrm{mld}$, which is much higher than the estimated discharge of wastewater in 2013. CPCB estimates shows that 64 industries in the mainstream of Ganga consume $1123 \mathrm{mld}$ of water and discharge $500 \mathrm{mld}$ of effluent. STPS are ineffective because of factors like lack of electricity, lack of connectivity with drain etc. that contributes $90 \%$ of Ganga water pollution. 3000mld of domestic wastewater is discharged into the river, which is roughly half of its total load. (14).

\begin{tabular}{c|cc} 
YEAR & $\mathbf{2 0 0 9}$ & $\mathbf{2 0 1 3}$ \\
\hline SEWAGE & 2638 & 2723 \\
GENERATION(MLD) & & \\
TREATMENT & 1174 & 1208 \\
CAPACITY(MLD) & & \\
GAP (MLD) & 1464 & 1514 \\
\% GAP & 55 & 55
\end{tabular}

Table 2: CPCB estimates the domestic sewage load on river Ganga from 2009-2013. Source: Status paper on River Ganga
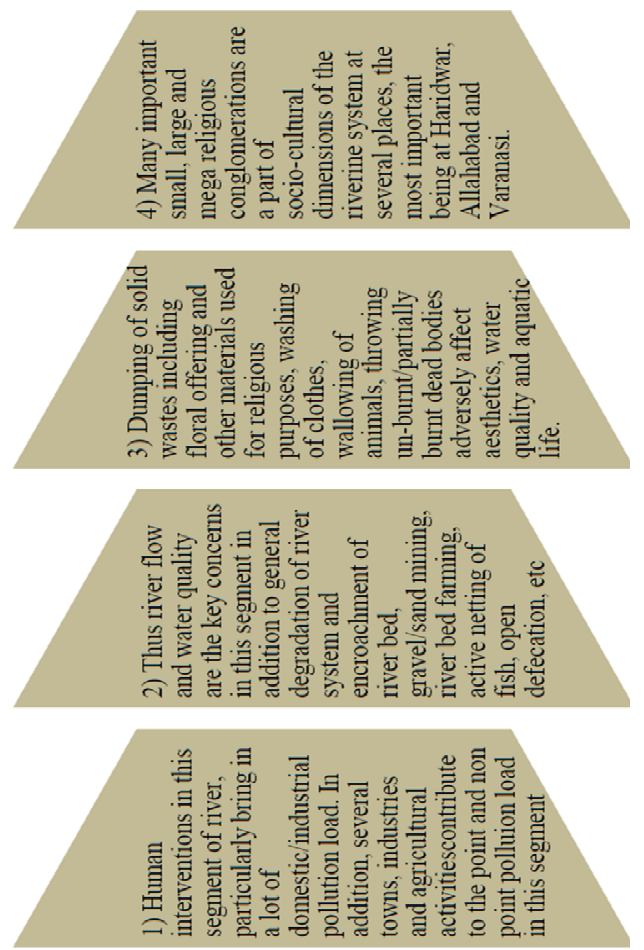

Fig 2: Represents factors causing pollution Source: Author 
Harmful complex compounds, which critically effect different biological functions and are of potential risk to aquatic ecosystem, animal, and humans. energy to fuel life processes and to replace energy loss as heat.

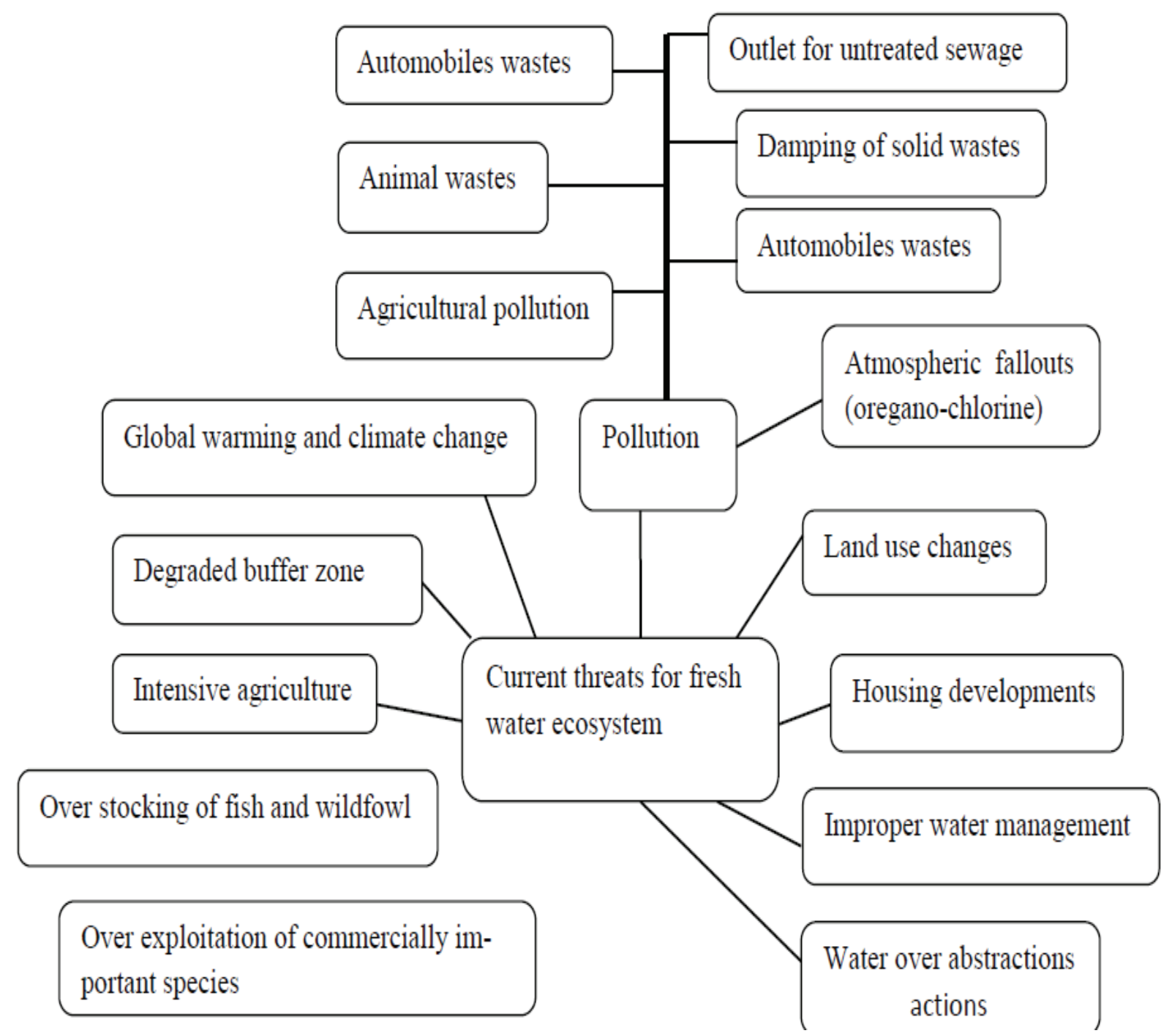

Fig 3: Represents summary of factors, which are threats for the sustainable functioning of River. Source: Author

\section{Food Chain in Fresh water Ecosystem (Kanpur-Bihar stretch)}

Fish population predominates depending upon grazing and detritus food chain. The next portion has Turtles, Crocodiles, Ghariyals and Gangetic Dolphin along with active breeding sites. Thus, there is one-way flow of energy through the biotic community and recycling of nutrients between the biotic and abiotic components of the ecosystem. Thus any ecosystem requires a continuous flow of
Phytoplankton's (Algae, diatoms) $\rightarrow$ Zooplanktons $\rightarrow$ Small Fish $\rightarrow$ Carnivorous fish $\rightarrow$ Grass $\rightarrow$ Rabbit

\section{$\rightarrow$ Fox}

The ultimate source of energy is Sun. The ultimate fate of energy in ecosystem is for it to be lost as heat, metabolism, reproduction, etc. energy and nutrients are passed from one organism to the another through the food chain as one eats another. Inorganic nutrients are cycled, Energy is not. Decomposers remove the last energy from the remains of organisms. 


\section{Producers (Phytoplanktons and Macrophytes)}

Is as the $1^{\text {st }}$ organism in the system, producers store and convert solar energy into living organisms. Phytoplankton (microorganisms) and large rooted plants (Macrophytes). Phytoplankton and plants are a food source of primary and secondary consumers

\section{Primary Consumers (Zooplanktons and Macro invertebrates)}

Zooplankton includes microscopic floating animals such as protozoan's, copepods, and amphipods. Macro invertebrates include midges, leeches, snails, and insect larvae. The primary consumers are the food source for small fishes.

\section{Secondary Consumers (Forage Fishes)}

Small (forage) fishes are the next tropic link in the system, feeds on plankton and small macro invertebrates, these forage fishes such as alewife, smelt and scalping provides much of the food for larger fishes.

\section{Tertiary Consumers (Large fishes, Birds and humans)}

Large fishes (piscivores) that feed on smaller fishes forms the next tropic level in the food chain. These larger fishes may include Salmon, lake trout, walleye and Bass. Other consumers of fishes include birds and mammals such as humans.

Fig 4: Represents the hierarchy of food chain in the eco-system Source: Author

How Water Pollution affects the Fresh water Ecosystem?

Wastewater and runoff carry micro plastics into waterways. $\rightarrow$ Plastic objects are broken down into smaller pieces by sunlight and surf/detergent actions. $\rightarrow$ Marine plastics are often mistaken for food. $\rightarrow$ Persistent bio accumulative and toxic
Compounds in freshwater ecosystem preferably sorbs to plastics. $\rightarrow$ Bioaccumulation may be amplified by plastics shuttling pollutants into marine organisms. $\rightarrow$ Potential plastic mediatedBioaccumulation. $\rightarrow$ At the same time, constituents of the plastic processes accumulate themselves such as additives leach into the tissues of the organisms that consume particles. Similarly 
compounds of heavy metals that are found in this stretch from industries and are toxic. organism excretes waste or dies, the nitrogen in its tissues is in the form of organic nitrogen Various

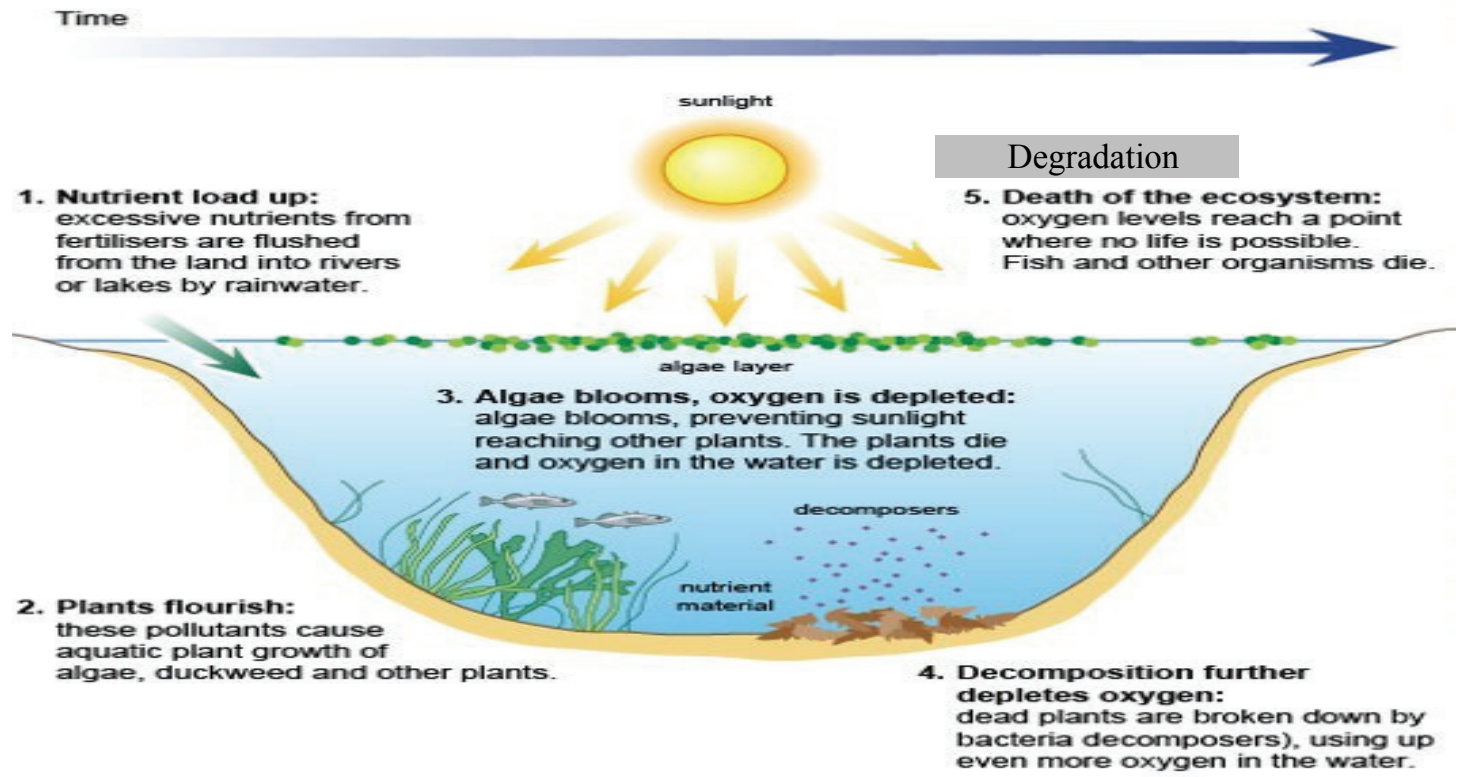

Fig 5: represents factors responsible for degradation of freshwater ecosystem Source: Effects of Pollution in Freshwater ecosystem

\section{Characteristics of Pollutants which leads to}

\section{Disturbances of Natural Processes}

Algae are microscopic plants that usually aquatic, unicellular, and lack stems, roots and leaves. Nitrates and Phosphates enter the system (such as sewage, fertilizers from agricultural run-offs) increased nutrients causes surface plant growth and algal blooms. It occurs in freshwater environment when an algal species out competes other species and reproduces rapidly. It kills fish and other aquatic life by decreasing available sunlight to water and by using all the available oxygen in the water, due to which water becomes cloudy and turns green, yellow brown or red, which lead eutrophication. It occurs when nitrite leaches into the water body and causes severe reduction in species diversity and water quality. Which results into the disturbance of Nitrogen cycle and Carbon cycle of the river. In aquatic environments (like freshwater- river), blue-green algae is an important free-living nitrogen fixer. Bacteria (called Nitrogen-fixing bacteria) form symbiotic relationships with host plants. The bacteria live in nodules found in the roots of the legume family of aquatic plants. When an fungi and prokaryotes then decompose the tissue and release inorganic nitrogen back into the ecosystem as ammonia in the process known as ammonification (Fig-8).The ammonia then becomes available for uptake by plants and other microorganisms for growth.

Further, as result disturbed Nitrogen cycle in surface water, extra nitrogen can lead to nutrient over-enrichment. This leads to fish-kills, harmful algal blooms, and species shifts in aquatic and land ecosystems. Some forms of nitrogen (like $\mathrm{NO}_{3}{ }^{-}$and $\mathrm{NH}_{4}{ }^{+}$) also enter the atmosphere to become smog- nitric oxide (NO), Greenhouse gasnitrous oxide $\left(\mathrm{N}_{2} \mathrm{O}\right)$ and Acid Rain- (nitrogen oxides) thus degrades the climate.

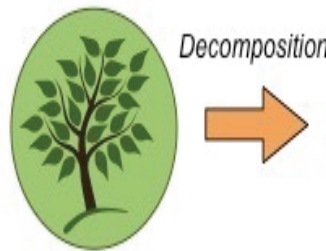

Plants / Animals

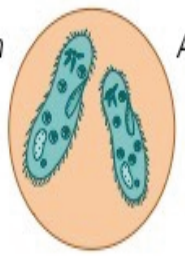

Soil Bacteria

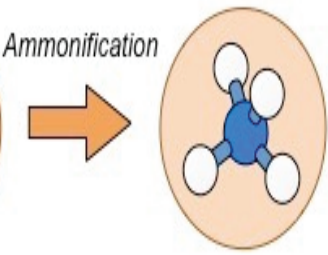

Ammonium $\left(\mathrm{NH}_{4}^{+}\right)$
Fig-6: Represents Process of Ammonification Source: Nitrogen Cycle ppt. 
In addition, Dissolved oxygen, also called DO, is vital to the health of aquatic ecosystem. Plants and animals need oxygen to survive. A low level of Dissolved oxygen in the rivers is affected by weather and temperature. It is important to monitor DO, since it can be used as an indicator of water quality. Algae produce oxygen during the day through photosynthesis but also quickly consume oxygen at night during respiration. Bacteria decompose the algae after the bloom dies, using a significant amount of oxygen in the process, which results in lack of available oxygen for other plants and animals Carbon dioxide, also called $\mathrm{CO} 2$, is found in water as a dissolved gas. It can dissolve in water 200 times more easily than oxygen. Aquatic plants depend on carbon dioxide for life and growth, just as fish depend on oxygen. Plants use carbon dioxide during the process of photosynthesis. Sometimes carbon dioxide levels in water become too high. Pollution causes too much carbon dioxide. Resulting into disturbance of $\mathrm{CO} 2$ cycle, which leads to the unhealthy state of ecosystem. In these conditions, fish have a hard time getting the oxygen they need from the water. Because of which they suffocate and die.

\section{How pollution affects Abiotic component}

Cold water holds more oxygen than warm water because Salmon needs a high level of oxygen to survive; they live in fast-moving, cold streams and rivers. Whereas warm-water fish such as bluegills, crappie, perch, walleye, catfish and carp can tolerate lower levels of dissolved oxygen in the water. Dissolved oxygen (DO) used as an indicator of water quality. Anoxia occurs when oxygen levels are low and often results when dry, hot weather causes water to warm and evaporation increases. If these conditions are severe, large "fish kills" (floating dead fish) may result due to lack of oxygen Carbon dioxide, also called $\mathrm{CO} 2$, is found in water as a dissolved gas. It can dissolve in water 200 times more easily than oxygen. Aquatic plants depend on carbon dioxide for life and growth, just as fish depend on oxygen. Thus for a healthy and sustainable ecosystem balance between Biotic and Abiotic has to be maintained.

1)Pollution sensitive species larvae vanished. This resulted into not only decline of fish population but other vertebrates as well. The use of orgenochlorine pesticides in agriculture posed new threats and resulted into accumulation in the tissues of fishes and higher vertebrates

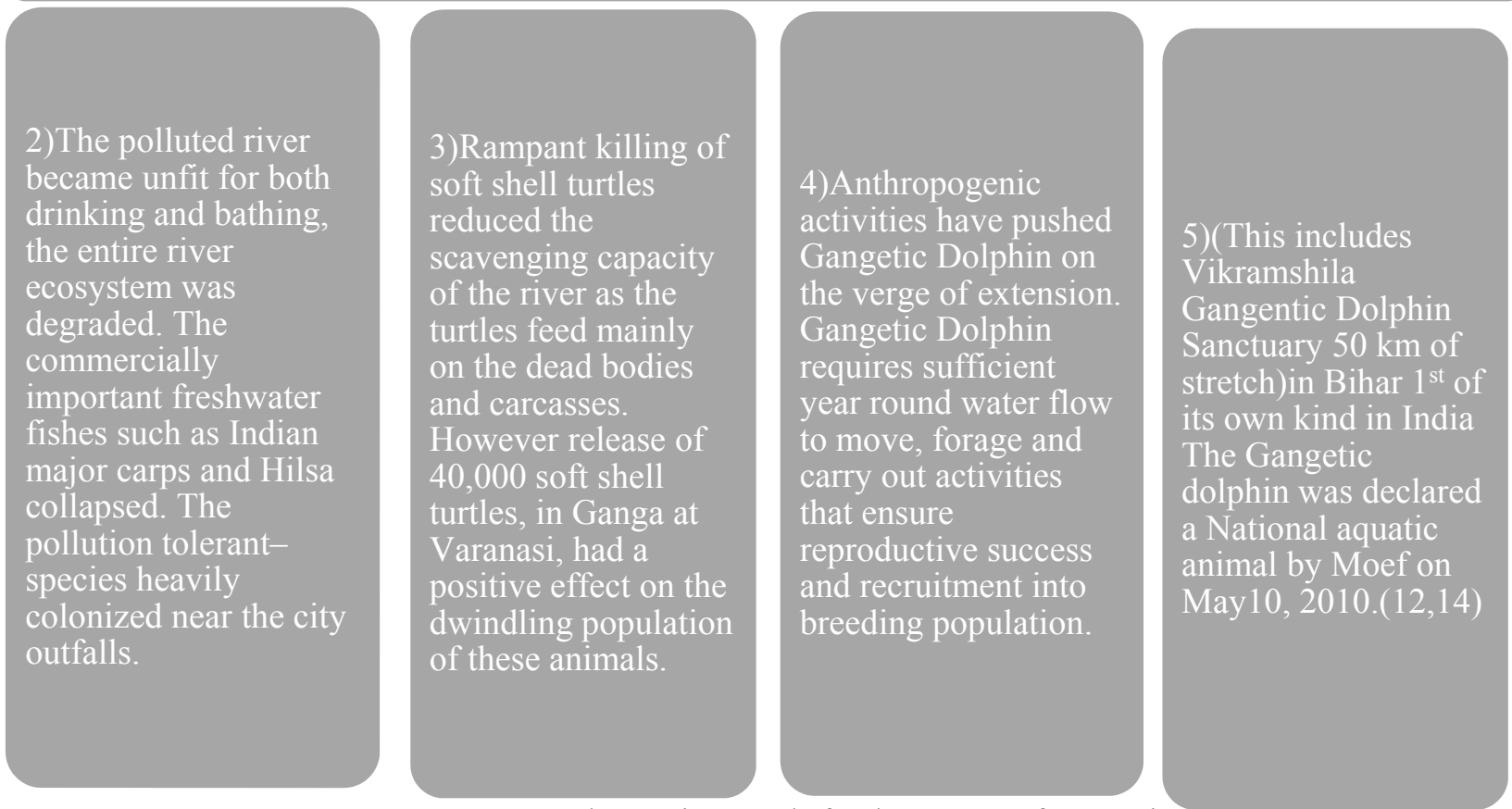

Fig7: represents observations made for the process of restoration Source: Author 
The BOD levels were higher and maximum values were recorded at Kanpur (Fig-2).

\section{Observations}

Among the five zones in the middle stretch of river Ganga, a total of 143 fish species belonging to 58 genera and 24 families were recorded. 29 species are threatened due to pollution in fresh water eco system. Schemes for Interception, diversion and Activated Sludge Process (ASP) and Oxidation Ponds were adopted for treatment of sewage, low cost sanitation, 28 electric crematoria and 5 Riverfront developments were successfully taken under Ganga Action Plan, phase I.

\section{Parameter Specific Observations}

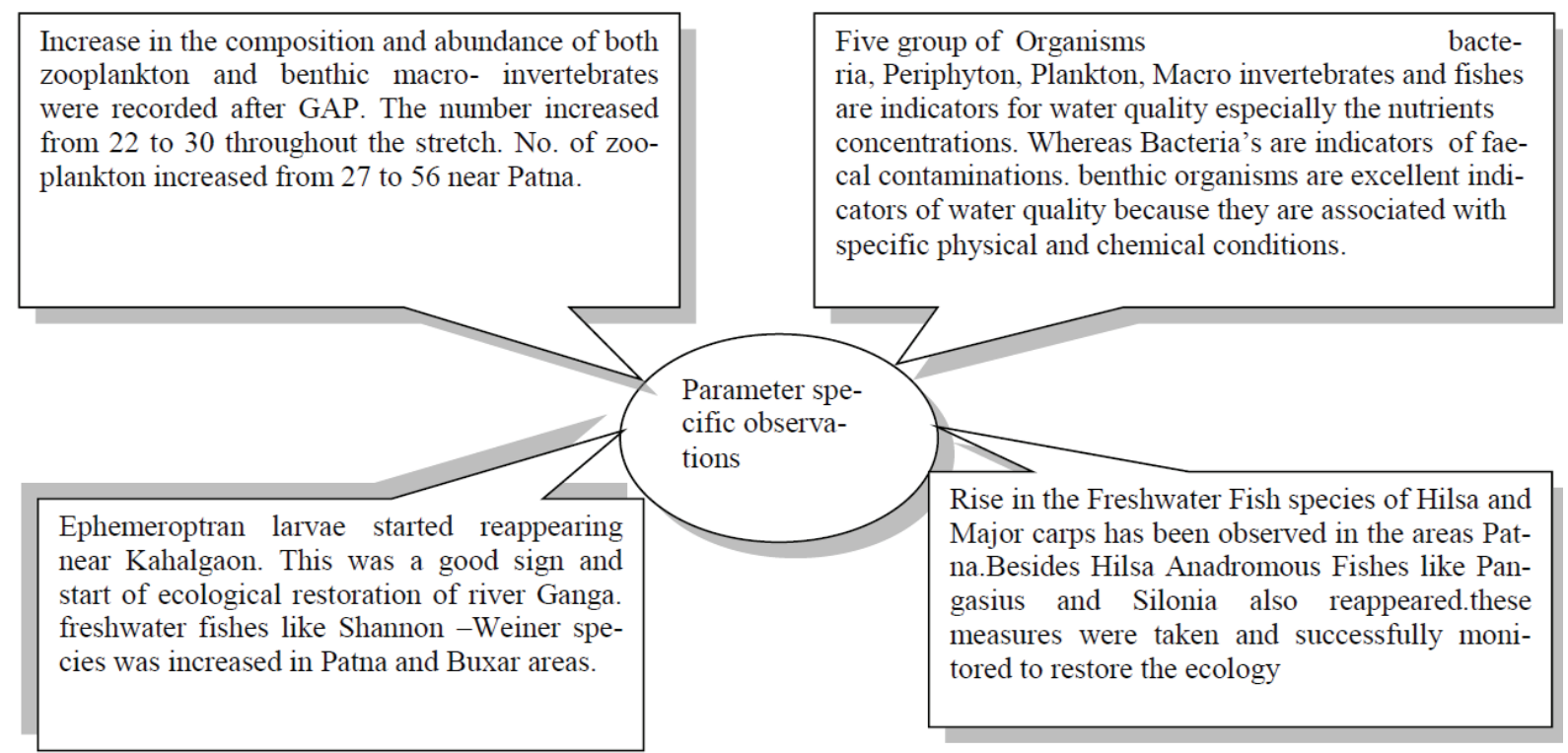

\section{Restoration Measures (Tools)}

The following restoration measures seem inevitable in river ecosystem to bring river Ganga to sustainable, stable and healthy condition.

a. To provide enough space for endemic(prevalent) species of both flora and fauna for growth and migration through Environmental Flows (E-Flows) by maintaining the lateral, vertical and longitudinal connectivity in the entire stretch of Ganga system.

b. To provide connectivity with wetlands. Restoration of wetlands may be made point of focus to ensure breeding sites of fish and other aquatic animals.

c. From the above study, it is evident to identify all the species including zoo benthos, fishes and aquatic higher vertebrates, which come under rare, endangered and threatened category, should be conserved to maintain ecological integrity. d. Breeding sites for fish and other higher aquatic vertebrates should be identified and con-served. Soft and hard-shelled turtles lay eggs in the flood plains during the post monsoon period. e. To assess and monitor river health, primary data collection for all parameters including bio monitoring from selected stretches should be done by recognized and reputed research institutions

ria, Periphyton, Plankton, Macro invertebrates and fishes indicators for water quality especially the nutrients cal contaminations -benthic organisms are excellent indicators of water quality because they are associated with specific physical and chemical conditions. 
The river basin is one of the most thickly populated areas of the world. It sustains thousands of aquatic species of flora and fauna including many endemic and charismatic mega-fauna like the Ganges dolphin, (12,14) Gavials etc. However, since 1950s the river is facing threats of erosion of its ecological integrity due to anthropogenic pressures in the form of construction of dams, barrages and embankments; loss of forest cover in its catchment area leading to heavy siltation, pollution from industrial effluents and domestic sewage degrading the water quality to the extent that the river water is not fit for even bathing purpose. Nevertheless, the river harbours rich and abundant aquatic biodiversity. The ecological changes cannot be attributed entirely to GAP but definitely it played an important role $(14,16)$. The Eco-Restoration of big river like Ganga is subsequent of this recovery, and requires constant efforts, monitoring time and patience.

\section{Recommendations and Suggestions}

a. Large daily fluctuations in flow should be avoided. Equilibrium between sediment erosion and deposition is necessary to maintain essential habitat features.

b. Access to flood plains should be preserved to ensure natural spawning and rearing habitat for fishes, which are prey base of the dolphins. Enhancing the capacity and governance framework for Gangetic Dolphin conservation is needed.

c. Information on the pre development ecological conditions of a river is essential for evaluating migration efforts and to implement future development decisions. Post development empirical studies are needed to monitor the operational aspects as well as the effects on upstream and downstream populations of cetaceans and their habitat.

d. Effective construction of fish passage structure is necessary. Conventional fish ladders de-signed may not be successful because most fishes do not jump. In the middle stretch of the river Ganges (Allahabad), which used to form a good share in catches below Allahabad, has almost disappeared after inception of Farakka barrage despite fish ladders were installed. Steps should be taken to improve fish pass way so that the fishes may negotiate upstream areas.

e. Cumulative and synergistic impacts of multi development should be considered in assessment of environmental impact.

\section{Reference}

Canli, M.; Ay. O. and Kalay, M. (1998): Level of heavy metals $(\mathrm{Cd}, \mathrm{Pb}, \mathrm{Cu}$ and $\mathrm{Ni})$ in tissues of Cyprinus carpio, Barbus capito and Chondrostoma regium from the Seyhan River Turkey. Journal of Zoology 22: 149-157.

Choudhary, S. (2012): "River Dolphin Distribution in Regulated River System; Implications for Dry Season Flow Regimes in the Gangetic Basin”, Aquatic Conservation: Marine and Freshwater Ecosystems. 22(1): 11-25.

Dirilgen, N. (2001): Accumulation of heavy metals in freshwater: Assessment of toxic interactions. Turkey Journal of Chemistry, 25: 173-179.

Hassan, S. S. "The Current Status of the Fish Stock of Commercial Importance in River Ganga in and Around Patna", op. cit., 152.

Lakra, W. S.; Sarkar, U. K.; Kumar, R. S.; Pandey, A.; Dubey, V. K. and Gusain, O. P. (2010): Fish diversity, habitat ecology and their conservation and management issues of a tropical River in Ganga basin, India. Environmentalist, 30(4): 306-319.

Matta, G. and Uniyal, D. P. (2017): Assessment of Species Diversity and Impact of Pollution on Limnological conditions of River Ganga. Int. J. Water, 11(2): 87-102. 
Matta, G. and Kumar, A. (2017): Health Risk, Water Hygiene, Science and Communication. ESSENCE Int. J. Env. Conser. Rehab, 8(1): 179-186.

Matta, G. and Kumar, A. (2017): Role of Science and Communication in health and hygiene: A case Study. ESSENCE Int. J. Env. Conser. Rehab, 5(2): 95-101.

Matta, G.; Laura, G.; Kumar, A. and Machel, J. (2018): Hydrochemical characteristics and planktonic composition assessment of River Henwal in Himalayan Region of Uttarakhand using CPI, Simpson's and Shannon-Weaver Index. Journal of Chemical and Pharmaceutical Sciences, 11(1).

Matta, G.; Kumar, A.; Gulshan, K. D.; Singh, P.; Laura, G. and Kumar, A. (2018): Limnological assessment of anthropogenic activities of River Henwal. Journal of Chemical and Pharmaceutical Sciences, 11(1).

Matta, G.; Kumar, A.; Kumar A, Naik PK, Kumar A (2018): Applicability of Heavy Metal Indexing on Ganga River System assessing heavy metals toxicity and ecological impact on river water quality. INAE Letters, an Official Journal of the Indian National Academy of Engineering.

Matta, G.; Kumar, A.; Naik, P. K.; Tiwari, A. K. and Berndtsson, R. (2018): Ecological Analysis of Nutrient Dynamics and Phytoplankton Assemblage in the Ganga River System, Uttarakhand. Taiwan Water Conservancy, 66(1): 1-12.

Matta, G.; Kumar, A.; Tiwari, A. K.; Naik, P. K. and Berndtsson, R. (2018): HPI appraisal of concentrations of heavy metals in Dynamic and static flow of Ganga River System. Environment, Development and Sustainability, Springer Nature.

Matta, G.; Kumar, A.; Uniyal, D. P.; Singh, P.; Kumar, A.; Dhingra, G. K.; Kumar, A.; Naik, P. K. and Shrivastva, N. G. (2017): Temporal assessment using WQI of River Henwal, a Tributary of River Ganga in Himalayan
Region. ESSENCE Int. J. for Env. Rehab. and Conser, 8(1): 187-204.

Matta, G.; Kumar, A.; Walia, A.; Kumar, S.; Mishra, H. K.; Dhingra, G. K.; Pokhriyal, P. and Wats, M. (2016): Quality estimation of ground water in industrial state of Uttarakhand. Pollution Research, 35(4): 849-854.

Matta, G.; Naik, P. K.; John, M.; Kumar, A.; Laura, G.; Tiwari, A. K. and Kumar, A. (2018): Comparative study on seasonal variation in hydro-chemical parameters of Ganga river water using comprehensive pollution index (CPI) at Rishikesh, (Uttarakhand) India. Desalination and Water Treatment, 118: 8795.

Natarajan, V. "Environmental Impact of Ganga Basin Development on Gene-pool and Fisheries of the Ganga River System", In Proceedings of the International Large River Symposium, ed. D. P. Dodge, Canadian Special

Sarkar, U. K.; Gupta, B. K. and Lakra, W. S. (2010): Biodiversity, ecohydrology, threat status and conservation priority of the freshwater fishes of river Gomti, a tributary of river Ganga (India). Environmentalist, 30(1): 3-17.

Sarkar, U. K.; Pathak, A. K.; Sinha, R. K.; Sivakumar, K.; Pandian, A. K.; Pandey, A. and Lakra, W. S. (2012): Freshwater fish biodiversity in the River Ganga (India): Changing pattern, threats and conservation perspectives. Reviews in Fish Biology and Fisheries, 22(1): 251272 .

Sharma, "Current status of Ganges Dolphin, Platanista Gangetica in River Son and Kosi in Bihar", Zoological Survey of India (ZSI), Faunal resources of Ganga. Part I, op. cit. 27-37.

Sinha, R. K. (1995): “Commercial Exploitation of Freshwater Turtle Resource inthe Middle 
Ganges River System in India", Proceedings of InternationalCongress of Chelonian Conservation, Gonfaron, France, 14-20.

Sinha, R. K. (1997): "Status and Conservation of Ganges River Dolphin in the BhagirathiHooghly River Systems in India", International Journal of Ecologyand Environmental Sciences, 23: 343-355.

Sinha, R. K. (2010): The Gangetic dolphin and Action Plan for its Conservation in Bihar, op.cit., 52.

Sinha, R. K. "The Ganges River Dolphin - A Tool for Baseline Assessment of Biological Diversity in River Ganges, India”. op.cit., 34

Sinha, R. K. and Kannan, K. (2014): “Ganges River Dolphin: An Overview of Biology, Ecology, and Conservation Status in India", op.cit.

Sinha, R. K. and Sharma, G. (2003b): "Current Status of Ganges Dolphin, Platanista gangetica in River Son and Kosi in Bihar", Journal of Bombay Natural History Society, 100: 27-37.

Sinha, R. K.; Behera, S. K. and Chaudhary, B. C. (2012): The Conservation ActionPlan for the Gangetic Dolphin, op. cit., 44.

Sinha, R. K.; Behera, S. K. and Chaudhary, B. C.(2010): The Conservation Action Plan for the Gangetic Dolphin 2010-20 (Ministry of Environment and Forests, Government of India, 44.

Sinha, R. K.; Nesemann, H. and Sharma, G. "New records of Physa (Gastropoda: Physidae) from Indian sub-continent”, op.cit.,3-11.

Smith, B. D. (2006): "Abundance of Irrawaddy Dolphins (Orcaella Brevirostris) and Ganges River dolphins (Platanista Gangetica Gangetica) Estimated Using
Concurrent Counts made by Independent Teams in Waterways of the Sundarbans Mangrove Forest in Bangladesh”, Marine Mammal Science, 22: 527-547.

Tiwari, A.; Kushwaha, A. S. and Dwivedi, A. C. (2015): Accumulation of heavy metals in liver, muscle and gill of Cyprinus carpio from the Ganga River at Varanasi, Uttar Pradesh. Journal of the Kalash Science 3: 47-51.

Voegborlo, R. B.; El-Methnani, A. M.; Abedin, M. Z. (1999): Mercury, cadmium and lead content of canned tuna fish. Food Chemistry, 67: 341-345.

Yang, Y.; Yun, X.; Liu, M.; Jian, Y.; Li, Q. X. and Wang, J. (2014): Concentrations, distributions, sources, and risk assessment of organochlorine pesticides in surface water of the East lake, China. Environmental Science and Pollution Research, 21: 3041-3050. 